
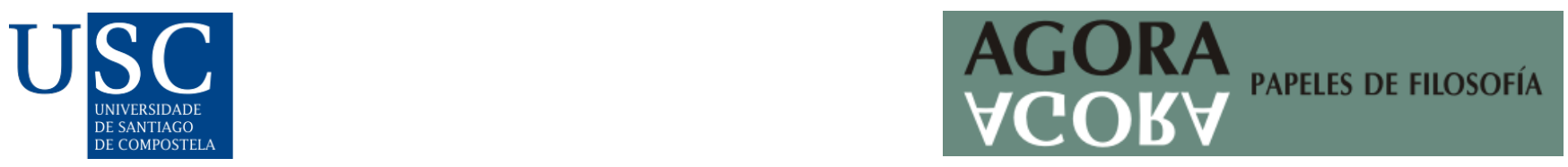

Agora. Papeles de Filosofía, 41(1), 2022. ISSN-e: 2174-3347

https://doi.org/10.15304/agora.41.1.7796

Recensiones

\title{
BERNARDO, Fernanda: Derrida - em nome da justiça. Do cosmopolitismo à alter-mundialização por vir, Palimage, Coimbra, 2021, 396p.
}

Hugo Monteiro

Recibido: 23/06/2021; Aceptado: 11/07/2021

Este livro incide principalmente na Desconstrução, de Jacques Derrida (1930-2004), como registo filosófico singular, tanto na História da Filosofia quanto no enfrentamento das mais justas exigências do tempo. E note-se, antes de mais, o modo como Fernanda Bernardo desdobra o gesto que analisa, na resistência aos imediatismos vigentes, no singular e rigoroso exercício de pensamento (sobre pensamentos) nutrido(s) pela responsabilidade ético-filosófica, que aqui se relê a si mesma. Por profundidade, alcance e abrangência, a filósofa de Coimbra propõe um exigente percurso de exigências, em torno de obras primaciais para uma outra escuta do pensamento contemporâneo: Paul Celan, Emmanuel Levinas e, principalmente, Jacques Derrida.

"O mundo está longe, eu tenho de portar-te". Este verso de Celan envolve, cruza e obsidia a marcha deste livro. É ele que conduz o ímpeto para repensar o cosmopolitismo, o direito e a hospitalidade, marcando as limitações do seu percurso no rumo do pensamento e assegurando ou reeditando tanto a sua urgência quanto a sua reponderação à luz de toda uma outra justiça. Reconsiderar a mundialização, no sentido de uma alter-mundialização, significa aqui repensar meta-ontofenomeno-logica-mente o político, o económico, o ambiental e todo o instituído, convocando toda uma outra "nova ordem mundial", sonhada no mais do que crítico desígnio de Derrida. No sentido de uma desconstrução da base de sustentação metafísica, pressuposta como ainda vigente no ocidente filosófico, cultural e político, este livro trata de escutar e de acompanhar o que sugestivamente se apresenta como "uma nova arca de Noé para o século XXI" (pp. 9-13). Sob este desígnio, e na cadência do referido verso de Paul Celan ("O mundo está longe, eu tenho de portar-te"), trata-se de esclarecer, reiterar e contra-assinar, ante os tão vincados desafios que nos marcam, o sonho e a "profissão de fé" de Derrida de uma "nova Internacional democrática".

Na cadência do verso de Celan e do sopro do seu meridiano poético, formula-se a necessidade de se pensar uma nova ética, repensada como uma outra ética, para além da tradição helénica, ontológica e humanista, sob os desígnios deste outro meridiano a par de toda a configuração do "mundo", fora do reduto metafísico e onto-fenomeno-lógico da filosofia, da cultura e da política que, com Celan, com Levinas, mas principalmente com Derrida, giza um novo começo e uma nova racionalidade para as inadiáveis urgências do século. A proposta de Fernanda Bernardo reclama uma responsabilidade que exceda a soberania do sujeito, os limites da cidadania ou da polis ou o privilégio do humano sobre os restantes viventes, para se afirmar como uma responsabilidade pela vida em geral.

Copyright $\odot$ Universidade de Santiago de Compostela. This is an open access article distributed under the terms of the Creative Commons Attribution-NonComercial-NoDerivatives 4.0 International (CC BY-NC-ND 4.0) License. 
A primeira parte da obra conjuga os principais filosofemas de Derrida, na sua professada afirmação de "um novo espírito das Luzes" (pp. 19-76). Recordando o alcance atuante e político de um gesto teórico que é, também, um "gesto de lúcida e de responsável resistência" (p. 69), trata-se de colocar sob suspeita o poder autonómico do sujeito, do soberano e de todo um modelo de soberania ainda configurado a partir do lugar do poder. A desconstrução da "soberania crática" implica o retraimento de uma política, cuja ancoragem continua a assentar na polis, nos territórios de pertença, nos limites fronteiriços do próprio como referencial de oposição ao estranho, em nome de uma repolitização orientada para a justiça incondicional, para a possibilidade do impossível e para a alteridade absoluta, abrangendo a totalidade dos viventes. Uma política fora da "estadolatria" (p. 34) - enfim retraçada como uma política voltada para a infinitude da justiça irradia necessariamente de toda uma outra ideia de "mundo", de "cosmos" e, como tal, de todo um outro cosmopolitismo, salvaguardado da territorialidade, da posse, da pulsão apropriadora que "o soberano tenta impor pela manha ou pela força, pela retórica, pela ideologia, pela escola ou pelo exército" (p. 103).

A segunda parte (pp. 81-232) trata do que excede os limites do cosmopolitismo, na sua delimitação conceptual moderna. Reencarada a questão sacrificial, que submete o vivente nãohumano à quase exclusiva medida humana da tradição filosófico-metafísica - de Platão/Aristóteles a Heidegger, sem excluir Levinas -, está em causa a singularidade da desconstrução de Derrida quanto à animalidade e ao animal.

É desde logo a própria subjugação do sensível ao horizonte conceptual do entendimento que sustenta, no fio da tradição, uma espécie de declaração de guerra ao vivente não-humano. Os vários episódios desta guerra permanente traçam o retrato de uma cultura alimentada pela oposição entre humanos e animais, num percurso de privilégio do que se convenciona ser próprio do humano e que moldou, nesses mesmos pressupostos, os regimes de hierarquia, de oposição e de poder reinantes no carno-falo-logo-centrismo de raiz metafísica, na sua história de sangue e de exclusão. Está em causa a confrontação com a história da fraternidade, como habitação fraternal do mundo entre iguais pela espécie humana, denunciando a sua marcha androcentrada em que a "humanidade viril" se constitui como modelo hegemónico de proximidade entre viventes humanos (pp. 165-206).

Afirma-se o "desafio da compaixão", como "novo contrato ético" alternativo à guerra sacrificial declarada e mantida pelas várias idades do humanoi/ homem. 0 apelo a uma nova locomoção do mundo, de um outro mundo, pontua uma alter-mundialização tocada pela alteridade absoluta, pela hospitalidade absoluta do outro, que é "todo e qualquer outro", levando de enxurrada os pressupostos metafísicos e soberanistas do modelo de uma mundialização dominante.

A terceira e última parte (pp. 237-391) deixa-se tocar especialmente por este segundo andamento do verso de Celan: “... eu tenho de portar-te”, como vínculo, como responsabilidade, como proximidade e hétero-afeção ante a nunca vencida distância do outro (pp. 237-255). Sublinhase o modo como "a arte do encontro poemático", de Celan, rompe com o horizonte das "filosofias do diálogo" a partir da experiência do poema no sentido pático, como um rastro da disjunção, como uma saudação a outrem, como um caminho in-finito para um "tu". o meridiano po-ético, de Celan, põe em questão o mundo como "casa própria" desenraizando-o, numa suspensão ao que, com segurança, se entendeu na condição humana como condição de poder soberano. Ressalta a obrigação ou a nova responsabilidade perante uma alteridade que fragmenta, de forma decisiva, toda a ideia de poder, ressoando de forma diferente pelos pensamentos da alteridade de Levinas (pp. 257-336) ou de Derrida (pp. 337-357), culminando com a "justiça ética" como modulação 
da Lei da hospitalidade incondicional, face às leis de direito da hospitalidade condicionada, e do cosmopolitismo outro como promessa da Desconstrução (pp. 358-391).

Neste último segmento do livro está em questão a proximidade (e distância) entre os pensamentos de Derrida e de Levinas, mas também o modo como este último filósofo abre a razão de uma ética, sulcando vias para pensar de novo a herança bíblica e helénica que a enforma, mas também apontando o facilitismo de uma doxa que limita o discurso ético a um confinado moralismo. Aqui, a leitura de Fernanda Bernardo é preciosa, não apenas por acautelar, com cuidado rigor, o registo de proximidade e a mais subtil das diferenciações entre Levinas e Derrida, mas também por realçar o alcance hiper-crítico destes pensamentos, apontando-os como setas ao coração do nosso tempo.

É à incondicionalidade da justiça que se dedicam os pontos derradeiros deste livro, no apelo a repensar a mundialização, o cosmopolitismo, as cidadanias de pertença e outras dimensões fundamentais inerentes ao Direito Internacional. Hoje, quando imperam ainda os trâmites de uma "soberania crática", onto-teologicamente modelada como "razão do mais forte" e perspetivável, por exemplo, nas várias priorizações do poder face aos viventes, nas águas do Mediterrâneo, nas fronteiras internas ou externalizadas da Europa e dos EUA, urge dar ouvidos à promessa da democracia porvir, de Derrida, uma "democracia universal, trans-estatal", que "desafia a nossa atenção, a nossa vigilância e a nossa responsabilidade, cientes de que um certo horizonte da promessa é também o da esperança" (p. 390).

É este sopro de justiça, assumidamente sonhado, mas nunca simplesmente utópico ou quimérico, que logra não desistir do cosmopolitismo, retomando-o a partir de toda uma outra respiração do mundo. 